\title{
Pengaruh Keberadaan Kilang Padi Keliling Terhadap Pendapatan Kilang Padi Menetap Di Kabupaten Aceh Utara
}

\author{
Devi Andriyani ${ }^{*} \mathrm{a}$, Zulkarnaini ${ }^{*} \mathrm{~b}$ \\ * Fakultas Ekonomi dan Bisnis Universitas Malikussaleh \\ a Corresponding author: Devisep80@gmail.com \\ b. zulkarnaini8november1993@ gmail.com
}

ARTICLE INFORMATION ABSTRACT

Keywords:

Priphery Rice Milling, Permanent

Rice Milling, Income.
The purpose of this research is to see the Influence of Mobile Rice Milling to Permanent Rice Milling Income in North Aceh District. The data used in this study is the primary data obtained from 63 respondents. The data analysis uses the Differential Test Model. The result of this study is that there is no difference in average income of permanent rice milling entrepreneurs before and after the emergence of mobile rice mill in North Aceh regency.

\section{PENDAHULUAN}

Letak geografis Indonesia diantara $6^{\circ} \mathrm{LU}-$ $11^{\circ} \mathrm{LS}$ dan $95^{\circ} \mathrm{BT}-141^{\circ} \mathrm{BT}$ oleh karena itu Indonesia merupakan daerah tropis. Indonesia juga merupakan negara Agraris karena sebagian besar penduduknya mempunyai mata pencaharian sebagai petani padi.

Proses penanaman padi harus memiliki skil yang tinggi. Karena mulai dari penggolahan tanah, pemilihan bibit unggul, penanaman, perawatan, pemupukan, pengairan, penyiangan, sampai pengolahan hasil pertanian membutuhkan waktu dan tenaga yang tidaklah sedikit ditambah lagi biaya untuk semua prosesnya. Berbeda dengan masyarakat industri yang menciptakan produk dengan menggunakan waktu yang sangat singkat dan dapat menikmati hasilnya dengan waktu yang cepat (Soekartawi, 2002).

Perubahan sosial merupakan perubahan yang terjadi karena usaha-usaha pembangunan dalam segala bidang meliputi: ekonomi, politik, bahasa, kesenian, hiburan, adat, teknologi dan lainlainnya yang tidak hanya terjadi pada individuindividu tetapi juga pada seluruh masyarakat.

Jasa kilang padi keliling merupakan bentuk dari adanya perubahan sosial yang dulunya hanya menetap dirumah, para pelanggan datang bila ingin menggunakan jasa kilang padi tersebut, tetapi dengan adanya perubahan zaman dan majunya tingkat teknologi maka alat teknologi pengigilngan padi pun dapat dipindah-pindahkan secara mudah ketempat lokasi pelanggan tersebut. Kilang padi keliling tercipta karena adanya inisiatif dari masyarakat agar memudahkan para petani guna mengolah hasil pertaniannya secara cepat.

Pengguna kilang padi keliling ini merupakan masyarakat lapisan menengah ke bawah yang ingin menekan biaya pengeluaran produksi dengan tujuan agar dapat terpenuhinya kebutuhan sehari-hari yang lain.

Praktik kilang padi menetap adalah salah satu usaha dibidangsektor industri yang digunakan sampai saat ini, disamping berkembangnya penggilingan padi keliling. Tetapi kedua usaha disektor ini masih dipakai secara bersama-sama oleh penduduk setempat.

Kilang padi keliling adalah suatu penggilingan padi yang dapat berpindah dari suatu lokasi ke lokasi yang dioperasikan menggunakan motor sebagai alat penggeraknya. Kemunculannya sempat menjadi masalah bagi penduduk di pedesaan. Alasan praktis, efesien, dan harga yang terjangkau sehingga banyak warga masyarakat 
pengguna jasa kilang padi dan juga efektif, tetapi hasil yang di peroleh tidak sesuai, padi yang dihasilkan lebih banyak yang pecah sehingga apabila dijual ke pasar harganya bisa turun drastis akibat kualitas yang rendah sedangkan hasil dari jasa kilang padi yang menetap di rumah, butir berasnya utuh dan kualitas yang dihasilkan bagus sehingga laku di jual di pasar-pasar. Jasa kilang padi yang menetap mempunyai izin usaha sedangkan jasa kilang padi tidak mempunyai izin usaha. Masyarakat pengguna jasa kilang padi keliling sudah mengetahui akan hal tersebut, tetapi kenapa masih banyak masyarakat menggunakan jasa kilang padi keliling, apakah karena keberadaannya yang mudah ditemui di jalan-jalan atau jumlahnya yang semakin banyak pada tiap musim panen? Ini menjadi suatu pertanyaan yang harus ditelusuri lebih lanjut agar diketahui alasan dari masyarakat dalam menggunakan jasa penggilingan padi tersebut dapat terungkap. Mungkin karena minimnya pengetahuan masyarakat tentang jasa kilang padi keliling sehingga hanya sekedar ikut-ikutan saja menggunakan jasa kilang padi keliling karena jasa kilang padi keliling kini menjadi sebuah "trend" di masyarakat sekitar.

Fenomena seperti ini memang kerap sekali kita jumpai dalam kehidupan masyarakat, di lain sisi terlihat jelas keunggulannya akan tetapi disisi lain juga terdapat kekurangan yang perlu diketahui. Kebanyakan masyarakat pengguna jasa kilang padi keliling sudah mengetahui baik dan buruk hasil proses akhir dari penggunaan jasa kilang padi tersebut. Mereka sudah berlangganan dari panen ke panen dari tahun ke tahun. Terlebih lagi masyarakat yang sebelumnya menggunakan kilang padi menetap kini beralih menggunakan jasa kilang padi keliling.

Munculnya kilang padi keliling telah menggeser fungsi dari kilang padi menetap, hal ini karena kilang padi keliling mempunyai pelanggan yang banyak. Ada juga penyedia jasa kilang padi keliling yang dapat dihubungi dengan "sms" (Short Message Service) atau telepon dengan begitu pelanggan dapat menikmati jasa kilang padi keliling tersebut, tidak harus menunggu jasa kilang padi keliling itu lewat, bahkan kilang padi keliling tersebut langsung menghampiri rumah pelanggan yang berminat ataupun langsung ke tempat penjemuran padi. Tidak perlu repot-repot lagi, tinggal menyebutkan lokasi tempat dengan seketika akan datang sesuai waktu yang diinginkan. Kilang padi keliling yang sering beroperasi di Kabupaten Aceh Utara yang memang dalam pengoperasian kerjanya keliling dari desa ke desa hingga dari Kecamatan satu ke Kecamatan yang lain.

Fenomena kemunculan kilang padi keliling sangat mempengaruhi terhadap pendapatan kilang padi menetap di Kabupaten tersebut, bahkan sebahagian pengusaha kilang padi menetap sudah meninggalkan kegiatan usaha ini.

Di Kabupaten Aceh Utara terdapat sebanyak 63 kilang padi menetap berdasarkan data yang didapatkan dari Dinas Perdagangan, Perindustrian, Koperasi dan Usaha Kecil Menengah aceh utara. Hal ini wajar karena daerah ini mempunyai lahan pertanian yang luas dan pekerjaan masyarakat didominasi oleh petani.

Dari hasil pra survey terhadap pengusaha kilang padi menetap di Kabupaten Aceh Utara yang dilakukan oleh penulis, menunjukkan bahwa tingkat pendapatan sebelum dan sesudah munculnya kilang padi keliling memiliki hasil yang berbeda pada setiap pengusaha. Sebahagian pengusaha menunjukkan ada perbedaan pendapatan sebelum dengan sesudah munculnya kilang padi keliling, tetapi sebahagian pengusaha menunjukkan tidak ada perbedaan pendapatan sebelum dengan sesudah munculnya kilang padi keliling. Berikut ini adalah hasil observasi awal terhadap kilang padi menetap sebagai berikut:

\section{Tabel 1}

Data Observasi Awal Di Kabupaten

Aceh Utara

\begin{tabular}{|c|l|c|c|}
\hline No & Nama Pengusaha & $\begin{array}{c}\text { Pendapatan } \\
\text { Setelah } \\
\text { Muncul } \\
\text { Puncul Kilang Padi } \\
\text { Keliling }\end{array}$ & $\begin{array}{c}\text { Kilang Padi } \\
\text { Keliling }\end{array}$ \\
\hline 1 & Usman Nur, S.E & Rp 8.000.000 & $\begin{array}{c}\text { Rp } \\
5.000 .000\end{array}$ \\
\hline 2 & M. Yusuf IB & Rp 4.000.000 & $\begin{array}{c}\text { Rp } \\
4.000 .000\end{array}$ \\
\hline 3 & Abdul Mutaleb & Rp 4.000.000 & $\begin{array}{c}\text { Rp } \\
3.000 .000\end{array}$ \\
\hline 4 & H.Ismail Nafi & Rp 7.000.000 & 7.000 .000 \\
\hline
\end{tabular}

Sumber: Observasi Awal, 2017

Berdasarkan tabel diatas menunjukkan bahwa pengusaha kilang padi menetap yaitu: 
Usman Nur, S.E dan Abdul Mutaleb menunjukkan adanya perbedaan pendapatan sebelum dan sesudah munculnya kilang padi keliling.

Perbedaan tersebut menunjukkan terjadi penurunan pendapatan pengusaha kilang padi menetap setelah munculnya kilang padi keliling. Sedangkan pengusaha kilang padi menetap lainya yaitu: M. Yusuf IB dan H.Ismail Nafi menunjukkan tidak ada perbedaan pendapatan sebelum dan sesudah munculnya kilang padi keliling. Hal ini disebabkan mereka memiliki modal yang besar untuk membeli gabah dengan cara memproduksi beras sendiri kemudian mendistibusikan beras tersebut ke pasar sehingga pendapatan mereka tidak dipengaruhi oleh munculnya kilang padi keliling. Penulis juga menemukan pengusaha kilang padi yang memiliki modal kecil tetapi tidak menunjukkan perbedaan pendapatan dengan munculnya kilang padi keliling.

Hal ini disebabkan masih ada masyarakat yang memilih kilang padi menetap daripada kilang padi keliling. Karena padi yang dihasilkan kilang padi keliling menjadi butir beras pecah-pecah sehingga apabila dijual ke pasar harganya bisa turun drastis akibat kualitas yang rendah sedangkan hasil dari jasa kilang padi yang menetap, butir berasnya utuh dan kualitas yang dihasilkan bagus sehingga laku di jual di pasarpasar. Dari uraian dan latar belakang masalah diatas, maka penulis sangat tertarik melakukan penelitian dengan judul "Pengaruh Keberadaan Kilang Padi Keliling Terhadap Pendapatan Kilang Padi Menetap Di Kabupaten Aceh Utara',

\section{TINJAUAN TEORITIS Pengertian Pendapatan}

Pendapatan merupakan hasil yang diperoleh seseorang dari usaha yang dilakukan. Pendapatan ini merupakan penghasilan dari penjualan jasa atau barang. Menurut (Rustam, 2010) mengamukakan bahwa pendapatan merupakan nilai maksimum yang dapat dikonsumsi oleh seseorang dalam satu priode dengan mengharapkan keadaan yang sama pada akhir seperti keadaan semula.
(Zaki, 2005) mengemukakan pendapatan adalah pendapatan dirtikan sebagai aliran masuk yang diterima oleh perusahaan menunjukkan peristiwa moneter yang menambah aktiva perusahaan sebagai akibat kegiatan produksi (penjualan) barang dan jasa.

\section{Faktor-faktor Yang Mempengaruhi Pendapatan Pengusaha}

Menurut (Zaki, 2005) menjelaskan bahwa ada beberapa faktor yang dapat menentukan tinggi rendahnya keadaan sosial ekonomi antara lain sebagai berikut:

\section{1) Tingkat Pendidikan}

Berkenaan dengan pendidikan, (Sumatmadja, 2008) mengemukakan bahwa : "Alternatif yang dapat dilakukan bagi pemecahan masalah rendahnya kualitas sumberdaya manusia ini adalah pembangunan dalam bidang pendidikan dalam arti yang seluas-luas nya". Negara yang sedang berkembang seperti Indonesia terdapat perbedaan yang cukup mencolok antara daerah pedesaan dengan daerah perkotaan dalam hal kesenangan, kekayaan dan distribusi hasil pembangunan. Perbedaan kesempatan untuk mendapatkan pendidikan antara daerah pedesaan dengan daerah perkotaan yang cukup mencolok. Penduduk diperkotaan memiliki kesempatan yang jauh lebih besar untuk dapat memasuki jenjang pendidikan yang lebih tinggi, jika dibandingkan dengan mereka yang tinggal di daerah pedesaan. Tingkat pendapatan yang rendah pada masyarakat pedesaan ini tentunya akan sangat berpengaruh pada keadaan sosial ekonomi. Usaha untuk mengadakan perubahan kearah tingkat kehidupan ekonomi yang lebih baik sering terhambat karena sikap masyarakat desa yang belum terbuka dengan hal baru dan inovasi baru.

\section{2) Mata Pencaharian}

Mata pencaharian penduduk suatu wilayah dipengaruhi oleh faktor alam dan tata nilai yang berlaku pada wilayah tersebut. Mata pencaharian penduduk yang tinggal didaerah dekat pegunungan dan daerah dataran akan berbeda jenis dan coraknya. Orang yang tinggal didaerah dekat pegunungan cenderung akan memanfaatkan lahan untuk pertanian lahan kering, sedangkan orang 
yang bertempat tinggal didaerah dataran dan ditunjang oleh air yang cukup akan cenderung memanfaatkan lahan untuk pertanian lahan sawah.

Usaha pertanian di pedesaan sangat tergantung pada luas pemilikan lahan pertanian serta pengetahuan dan kemampuannya mengolah lahan untuk meningkatkan produktivitasnya. Sehingga dengan adanya usaha petani maka munculah usaha baru seperti jasa kilang padi keliling merupakan bentuk dari adanya perubahan sosial yang dulunya hanya menetap dirumah, para pelanggan datang bila ingin menggunakan jasa kilang padi tersebut, tetapi dengan adanya perubahan zaman dan majunya tingkat teknologi maka alat teknologi pengigilngan padi pun dapat dipindah-pindahkan secara mudah ketempat lokasi pelanggan tersebut.

\section{3) Tingkat Pendapatan}

Pendapatan adalah perolehan barang atau uang yang diterima atau dihasilkan oleh seseorang. Besar kecilnya pendapatan seseorang disebabkan oleh beberapa faktor antara lain faktor modal, faktor pendidikan dan faktor kewirausahaan.

Penduduk pedesaan yang sebagian besar mata pencahariannya sebagai petani, tingkat pendapatannya masih tergantung pada luas lahan pertanian yang merupakan faktor modal, karena pada umumnya petani di Indonesia masih memiliki tongkat pendidikan, pengetahuan, kemampuan serta jiwa kewiraswastaan yang relatif masih rendah. Seperti dikemukakan sebelumnya bahwa kepemilikan lahan pertanian oleh petani pada umumnya adalah masih semipit, dengan demikian, pendapatan kebanyakan petani yang merupakan mayoritas penduduk pedesaan masih sangat rendah.

\section{4) Kondisi Kesehatan}

Dalam bukunya, (Armiati, 2007) mengemukakan bahwa "Kondisi kesehatan masyarakat masih menunjukan tingginya angka kelahiran, masih banyaknya berjangkit penyakit menular dan infeksi, terutama menyerang balita dan anak-anak, masih rendahnya pengertian masyarakat terhadap pemeliharaan kesehatan secara modern, gizi dan sanitasi yang buruk merupakan faktor yang menjadi penyebab rendahnya tingkat kesehatan penduduk pedesaan.
Perbaikan kesehatan masyarakat pedesaan dilakukan dengan cara mendekatkan pusat pelayanan kesehatan, pada penduduk pedesaan, usaha perbaikan terutama ditujukan pada pemberantasan penyakit menular, peningkatan gizi rakyat, peningkatan penyediaan air bersih dan sanitasi lingkungan serta pelayanan kesehatan lainnya. hal ini dikarenakan dengan adanya peningkatan kesehatan bagi masyarakat maka meningkat pula tingkat pendapatan karena masyarakat dapat bekerja dengan baik.

Menurut Kimin dalam (Suzana, 2007) pendapatan adalah money income atau real income. Money income adalah pendaptan yang diterima seseorang atau golongan yang berupa uang dalam jangka waktu tertentu, real income adalah pendapatan yang diterima seseorang atau golongan dalam bentuk barang dan jasa waktu tertentu.

\section{Kerangka Konseptual}

Gambar 1

Kerangka Konseptual

\begin{tabular}{|c|c|}
\hline $\begin{array}{c}\text { Pendapatan } \\
\text { Sebelum } \\
\text { Muncul } \\
\text { Kilang Padi }\end{array} \stackrel{\text { Uji Beda }}{\longrightarrow} \begin{array}{c}\text { Pendapatan } \\
\text { Sesudah } \\
\text { Muncul } \\
\text { Kilang Padi }\end{array}$ \\
\hline
\end{tabular}

\section{Hipotesis Penelitian}

Ho: Tidak terdapat perbedaan pendapatan pengusaha kilang padi menetap sebelum dan sesudah muncul kilang padi keliling di Kabupaten Aceh Utara.

Ha: Terdapat perbedaan pendapatan pengusaha kilang padi menetap sebelum dan sesudah muncul kilang padi keliling di Kabupaten Aceh Utara.

\section{METODE PENELITIAN}

\section{Objek dan Lokasi Penelitian}

Objek penelitian ini adalah pendapatan pengusaha kilang padi menetap sebelum dan sesudah muncul kilang padi keliling di Kabupaten Aceh Utara. Adapun lokasi penelitian adalah di Kabupaten Aceh Utara. 


\section{Populasi}

Menurut (Arikunto, 2006) populasi adalah keseluruhan dari subjek penelitian (semua elemen yang ada di dalam wilayah penelitian). Sedangkan menurut (Kounter, 2007) populasi adalah kumpulan yang menyeluruh dari suatu objek yang merupakan perhatian peneliti, objek penelitian dapat berupa makhluk hidup, benda, system dan prosedur, fenomena dan lain-lain.

Berdasarkan data yang didapatkan dari Dinas Perdagangan, Perindustrian, Koperasi dan Usaha Kecil Menengah Kabupaten Aceh Utara jumlah pengusaha kilang padi menetap di Kabupaten itu sebanyak 63 orang. Dengan demikian yang dijadikan populasi dalam penelitian ini adalah pengusaha kilang padi menetap di Kabupaten ini yang berjumlah 63 orang.

\section{Sampel}

Sampel adalah bagian terkecil dari populasi. Dalam penelitian ini teknik pengambilan sampel yang digunakan adalah Metode Sensus, yaitu penarikan sampel dengan menggunakan semua anggota populasi yang berjumlah 63 orang pengusaha kilang padi menetap.

\section{Teknik Pengumpulan Data}

Untuk memperoleh data yang lengkap harus menggunakan metode dan sistematika yang tepat. Oleh karena itu, metode yang digunakan oleh penulis dalam penelitian ini adalah :

\section{Field Research (Riset Lapangan)}

Field Research merupakan penelitian lapangan untuk memperoleh data primer dengan teknik pengumpulan data :

a. Kuesioner

Menurut (Arikunto, 2006) kuesioner adalah sejumlah pertanyaan yang digunakan untuk memperoleh informasi dari responden dalam arti laporan tentang pribadinya atau hal-hal yang diketahuinya.

b. Pengamatan (Observation)

Menurut (Sunyoto, 2011) observasi adalah metode yang digunakan oleh peneliti dengan cara pengamatan langsung terhadap kegiatan yang dilaksanakan perusahaan. Teknik pengumpulan data yang dimaksud yaitu untuk mengamati pengaruh keberadaan kilang padi keliling terhadap pendapatan pengusaha kilang padi menetap di Kabupaten Aceh Utara.

2. Library Research (Studi Kepustakaan)

Menurut (Arikunto, 2006) Studi pustaka adalah metode pengumpulan data dengan cara mencari informasi melalui buku-buku, koran, majalah dan literature lainnya. Dalam hal ini pengumpulan data dilakukan dengan membaca dan mempelajari tulisan-tulisan berupa buku-buku literature dan sumber bacaan lainnya yang berkaitan dengan objek pembahasan sebagai landasan teori.

\section{Definisi Operasional Variabel}

Menurut (Nazir, 2003) menyebutkan bahwa definisi operasional variabel adalah suatu definisi yang diberikan kepada suatu variabel atau konstrak dengan cara memberikan arti atau menspesifikan kegiatan ataupun memberikan suatu operasional yang digunakan untuk mengukur konstrak atau variabel tertentu.

Untuk menghindari kesalahan dalam mengartikan variabel-variabel yang dianalisis untuk membatasi permasalahan dalam penelitian ini, perlu dijelaskan definisi operasional untuk masimg-masing variabel.

Variabel yang dimaksudkan dalam penelitian ini adalah :

a. Pendapatan

Pendapatan adalah Sejumlah penerimaan yang diperoleh pengusaha kilang padi menetap sebelum dan sesudah munculnya kilang padi keliling di Kabupaten Aceh Utara dari hasil pekerjaannya pada periode tertentu (per bulan) yang diukur dalam satuan mata uang (rupiah).

\section{Metode Analisis Data}

Analisis data merupakan suatu proses pengolahan data yang telah dikumpulkan sebelumnya. Hal ini dilakukan agar kesimpulan yang di peroleh dapat dipertanggung jawabkan secara ilmiah. Dalam penelitian ini analisa data yang digunakan adalah sebagai berikut:

Analisis yang digunakan untuk mengolah data yang berjumlah besar dan bisa di klasifikasikan serta diukur. Dalam penelitian ini akan digunakan alat analisis yaitu uji beda $\mathrm{T}$ dengan bantuan SPSS.

Dalam penelitian ini dilakukan dengan menganalisis apakah terdapat perbedaan yang 
signifikan terhadap pendapatan pengusaha kilang padi menetap sebelum dan sesudah munculnya kilang padi keliling di Kabupaten Aceh Utara dengan bantuan Aplikasi SPSS, Uji Beda (Paired Sample T-test).

Paired Sample T-test digunakan untuk menentukan ada tidaknya perbedaan rata-rata dua sampel bebas yang berpasangan (Ghozali, 2005).

Uji statistik untuk pengujian hipotesis data berpasangan dinyatakan sebagai berikut: $t=\frac{D}{s d / \sqrt{n}}$ Dan standar deviasi (sd) dirumuskan sebagai berikut :

$$
\begin{aligned}
& S D=\sqrt{\frac{\sum \mathrm{D}^{2}-\frac{\left(\sum \mathrm{D}^{2}\right)}{n}}{n-1}} \\
& D=\frac{\sum D}{n}
\end{aligned}
$$

\section{Dimana:}

$\mathrm{t}$ : Nilai distribusi $\mathrm{t}$

$D \quad$ : Perbedaan nilai rata-rata dua sampel

SD : Perbedaan deviasi standar dua sampel

$\mathrm{N}$ : Jumlah observasi didalam sampel ke 1 atau sampel ke 2.

Pengujian:

\section{Hipotesis}

Ho : Pendapatan rata-rata pengusaha kilang padi menetap sebelum dan sesudah muncul kilang padi keliling adalah sama.

Ha : Pendapatan rata-rata pengusaha kilang padi menetap sebelum dan sesudah muncul kilang padi keliling adalah beda.

1. Tingkat Signifikansi : $\alpha=0,05$

2. Kriteria Pengujian:

Ho diterima jika $\mathrm{t}$ hitung $\leq \mathrm{t}$ tabel, dengan $\mathrm{df}=$ (n-1)

Ho ditolak jika $t$ hitung $>\mathrm{t}$ tabel, dengan $\mathrm{df}=$ (n-1)

\section{HASIL PENELITIAN DAN PEMBAHASAN}

\section{Hasil Uji Beda}

Uji beda digunakan untuk menganalisis hasil-hasil pengamatan yang berpasangan dari dua data, apakah berbeda atau tidak. Dalam penelitian ini menganalisis perubahan pada variabel pendapatan/omset usaha kilang padi menetap sebelum dan sesudah munculnya kilang padi keliling.

Suatu usaha dapat dikatakan berkembang salah satunya dengan melihat besaran nominal pendapatan/omset. Hasil analisis menggunakan uji beda mengenai pendapatan/omset usaha kilang padi menetap sebelum dan sesudah munculnya kilang padi keliling dapat dilihat sebagai berikut:

Tabel 2

\begin{tabular}{|c|c|c|}
\hline & \multicolumn{2}{|c|}{ Pendapatan } \\
\hline & Sebelum & Sesudah \\
\hline $\mathbf{N}$ & 63 & 63 \\
\hline Mean & 6603174,6032 & 6404761,9048 \\
\hline Korelasi & 0,951 & \\
\hline Sig. Korelasi & 0,000 & \\
\hline $\mathbf{T}_{\text {hitung }}$ & 0,746 & \\
\hline Sig. (2-tailed) & 0,458 & \\
\hline $\mathbf{T}_{\text {tabel }}$ & 1,66980 & \\
\hline Df & 62 & \\
\hline
\end{tabular}

Deskriptif Hasil Uji Beda

Sumber: Lampiran (data diolah), 2017

Dari tabel di atas terlihat bahwa nilai ratarata pendapatan usaha kilang padi menetap sebelum dan sesudah munculnya kilang padi keliling di Kabupaten Aceh Utara. Sebelum munculnya kilang padi keliling rata-rata pendapatan usaha kilang padi pada 63 pengusaha adalah Rp 6.603.174,60,-. Sementara Sesudah munculnya kilang padi keliling rata-rata pendapatan usaha kilang padi menetap pada 63 pengusaha adalah $\mathrm{Rp} 6.404 .761,90,-$. Dari hasil tersebut dapat disimpulkan bahwa selisih pendapatan pengusaha kilang padi menetap sebelum dan sesudah munculnya kilang padi keliling tidak jauh berbeda. Hal ini disebabkan rata-rata pengusaha kilang padi menetap di Kabupaten Aceh Utara memiliki modal yang besar untuk membeli gabah dengan cara memproduksi beras sendiri kemudian mendistibusikan beras tersebut ke pasar sehingga pendapatan mereka tidak dipengaruhi oleh munculnya kilang padi keliling.

Berdasarkan tabel 2 di atas, maka diketahui nilai koefesien korelasi (R) antara dua variabel berpasangan sebesar 0,951 dengan signifikan 0,000 bermakna bahwa hubungan antara dua ratarata pendapatan usaha kilang padi menetap sebelum dan sesudah munculnya kilang padi 
keliling adalah sangat kuat dan signifikan yaitu sebesar $95,1 \%$.

\section{Pembuktian Hipotesis Uji Beda}

Pengujian uji beda dilakukan untuk mengetahui perbedaan rata-rata pendapatan usaha kilang padi menetap di Kabupaten Aceh Utara pada 63 pengusaha sebelum dan sesudah munculnya kilang padi keliling. Dengan membandingkan nilai $t_{\text {hitung }}$ dengan $t_{\text {tabel }}$. Kriteria pengujiannya adalah apabila nilai $t_{\text {hitung }}>t_{\text {tabel }}$ maka terdapat perbedaan yang signifikan rata-rata pendapatan usaha kilang padi menetap sebelum dan sesudah munculnya kilang padi keliling di Kabupaten itu, sebaliknya jika $t_{\text {hitung }}<t_{\text {tabel }}$ maka tidak terdapat perbedaan yang signifikan rata-rata pendapatan usaha kilang padi menetap sebelum dan sesudah munculnya kilang padi keliling. Adapun nilai $t_{\text {tabel }}$ pada $\mathrm{df}=\mathrm{n}-\mathrm{k}(63-1=62)$ dengan tingkat keyakinan $95 \%$ atau tingkat signifikan 0,05 yaitu sebesar 1,66980.

Diketahui bahwa thitung 0,746 dan tingkat signifikan adalah $0,458>0,05$ sedangkan $\mathrm{t}_{\text {tabel }}$ 1,66980 yaitu $\mathrm{df}=\mathrm{n}-\mathrm{k}$. Oleh karena itu $\mathrm{t}_{\text {hitung }}<\mathrm{t}_{\text {tabel }}$ sehingga dapat disimpulkan bahwa Ho diterima dan Ha ditolak. Jadi dapat dikatakan tidak terdapat perbedaan rata-rata pendapatan pengusaha kilang padi menetap sebelum dan sesudah muncul kilang padi keliling.

\section{KESIMPULAN DAN SARAN Kesimpulan}

Berdasarkan hasil penelitian yang telah dikemukakan pada bab sebelumnya, maka dapat diambil beberapa kesimpulan sebagai berikut:

1. Hasil penelitian menunjukkan bahwa tidak terdapat perbedaan rata-rata pendapatan pengusaha kilang padi menetap sebelum dan sesudah muncul kilang padi keliling di Kabupaten Aceh Utara dengan kata lain tidak ada pengaruh munculnya kilang padi keliling terhadap pendapatan kilang padi menetap di Kabupaten tersebut.

2. Koefesien korelasi (R) antara dua variabel berpasangan sebesar 0,951 dengan signifikan 0,000 bermakna bahwa hubungan antara dua rata-rata pendapatan usaha kilang padi menetap sebelum dan sesudah munculnya kilang padi keliling di Kabupaten Aceh Utara adalah sangat kuat dan signifikan yaitu sebesar $95,1 \%$.

\section{Saran}

Berdasarkan hasil penelitian dan kesimpulan yang dikemukakan di atas, maka penulis merumuskan beberapa saran sebagai berikut:

1. Untuk meningkatkan pendapatan usaha kilang padi menetap di Kabupaten Aceh Utara disarankan pengusaha menyisihkan sebahagian hasil keuntungan yang telah diperoleh untuk menambah modal dagangan sehingga dapat terus mengembangkan usahanya.

2. Pedagang harus benar-benar memnafaatkan pengalaman dalam berwira usaha sehingga dapat meningkatkan pendapatannya.

3. Penelitian ini dapat menjadi bahan referensi untuk penelitian selanjutnya tentang faktorfaktor yang mempengaruhi pendapatan dan kepada penelitian selanjutnya dapat menguji ulang dengan menanbah variabel lain seperti harga jual dan lokasi berdagang yang tidak dimasukkan dalam penelitian ini, sehingga dapat menyempurnakan penelitian-penelitian selanjutnya.

\section{DAFTAR PUSTAKA}

Arikunto. 2006. "Prosedur Penelitian Suatu Pendekatan Praktek. Edisi V." Jakarta: PT. Rineka Cipta.

Armiati, S. dan S. S. Sastramihardja. 2007. Collaborative Learning Framework. Seminar Nasional Aplikasi Teknologi Informasi 2007 (SNATI 2007).

Ghozali, Imam. 2005. "Aplikasi Analisis Multivariate Dengan Program SPSS. Edisi 1." Semarang: Badan Penerbit Universitas Diponogoro.

Kounter, Romi. 2007. "Metode Penelitian Untuk Penulisan Skripsi Dan Tesis. Edisi Revisi." Jakarta: Penerbit PPM.

Nazir, Moh. 2003. "Metode Penelitian. Cetakan Kelima." Jakarta: Penerbit Ghalia Indonesia. 
Rustam. 2010. "Makro Ekonomi Moderen." Jakarta: Raja Grafindo Persada.

Soekartawi. 2002. "Analisis Usaha Tani." Jakarta: Universitas Indonesia.

Sugiyono. 2008. "Motode Penelitian Bisnis." Bandung: Penerbit CV. Alfabeta.

Sumatmadja. 2008. "Tatanan Sosial Masyarakat." Yogyakarta: Sinar Wijaya.

Sunyoto, Danang. 2011. "Metodologi Penelitian Ekonomi." Jakarta: Penerbit CAPS.

Supranto. 2009. "Metode Riset Aplikasinya Data Pemasaran. Edisi Revisi Ketujuh." Jakarta: Penerbit Rineka Cipta.

Suzana. 2007. "Tanaman Sosisal Masyarakat." Yogyakarta: Graha Ilmu.

Wiryanto, J. Frans. 2001. "Membangun Masyarakat." Bandung: Offset Alumni.

Zaki. 2005. "Analisis Faktor Yang Mempengaruhi Tingkat Kemiskinan." Jogjakarta: UNDIP. 